\title{
MENYOAL KOMUNITAS PUNK DI ACEH DALAM PERSPEKTIF DIFFERENTIAL ASSOCIATION
}

\author{
Cut Irna Liyana, M.A. \\ Dosen Tetap Program studi Ilmu Sosiologi
}

\begin{abstract}
In recent years, Punk widely reported presence in Aceh. The existence of this community is predicted disturbing the lives of people in Aceh. So it becomes a problem that must be dealt with thoroughly. Therefore, this paper examines and describes the punk community as one form of social deviation in the differential perspective association. As of studies conducted, resulting that punk was present in Aceh today is the result of interaction with foreign cultures (other cultures). it can be proven by further examining the activities and behavior of teenagers who called himself punker, much of Aceh culture is loaded with Islamic law. Efforts to do to overcome this community, namely: providing guidance; developing policies that focus on social issues, improving the education system, increasing social control and control of the family.
\end{abstract}

Key words: Community, Punk, deviant behavior, differential association.

\section{Pendahuluan}

Manusia merupakan makhluk sosial yang hidup berdampingan dan tidak dapat menjalankan hidupnya secara sendiri karena sifatnya yang memiliki ketergantungan dengan manusia lainnya. Ketergantungan ini kemudian menyebabkan manusia melakukan interaksi dengan sesama manusia agar dapat memenuhi kebutuhan hidupnya. Dari interaksi inilah kemudian lahir konsepsi kehidupan yang disebut sebagai masyarakat.

Dalam interaksinya didalam masyarakat, manusia mengalami apa yang dinamakan proses sosial. Kemudian pada akhirnya proses sosial ini akan melahirkan produk sosial yang dikenal sebagai norma. Dalam melakukan interaksi, pada kenyataannya tidaklah selalu mulus begitu saja tanpa adanya pertentangan. Pertentangan ini terjadi karena adanya perbedaan kebutuhan hidup seseorang. 
Untuk menghindari pertentangan tersebut, manusia membutuhkan suatu tatanan masyarakat yang mengatur interaksi antar individu yang berada dalam masyarakat. Tatanan inilah yang kemudian disebut norma sosial. Kajian sosiologi tentang norma kemudian berhubungan dengan kajian sosiologi tentang penyimpangan sosial, yaitu situasi ketika masyarakat menganggap orang dan perilaku tertentu yang dianggap melanggar aturan dan konvensi sosial yang ada. Pada kenyataannya, penyimpangan sosial terdapat dalam kehidupan sehari-hari, seperti homoseksual, prostitusi, mengkonsumsi narkotika dan obat terlarang, pornografi dan pornoaksi.

Beberapa tahun belakangan ini, komunitas punk telah menjamuri hampir semua provinsi di Indonesia, tak terkecuali Aceh. Keberadaan komunitas punk yang umumnya terdiri dari kaum muda berusia berkisar belasan tahun, marak diberitakan meresahkan masyarakat Aceh, khususnya di kota Banda Aceh. Anak punk, sebutan untuk remaja yang berasal dari komunitas punk merupakan salah satu gejala proses sosial yang melahirkan pelanggaran norma sosial.

Gaya hidup punker (demikian mereka menyebut dirinya) tentu saja berbeda dari kehidupan remaja pada umumnya. Mulai berpenampilan dengan gaya rambut Mohawk, tindikan, memakai pakaian serba hitam, dan dengan baju serta celana ketat, sudah membedakan mereka dengan remaja pada umumnya. Belum lagi gaya hidup yang tidak mandi berminggu-minggu, tidak sekolah, tidak pulang kerumah orang tua, tidur dijalan dan taman kota, ada yang mengkonsumsi narkotika bahkan bercampur antara lawan jenis (kumpul kebo) ini jelas mengganggu kenyamanan masyarakat dan tentu saja sangat jauh dari kebudayaan Aceh yang sarat dengan syariat.

Kehidupan mereka yang membuat orang merasa tidak nyaman tersebut, membuat apa yang mereka lakukan adalah sebagai salah satu penyimpangan sosial yang berasal dari proses perubahan sosial, yang semestinya harus dicegah sejak dini. Karena jika dihubungkan dengan cerminan masyarakat Aceh, Punk tersebut sangatlah jauh dari kebudayaan Aceh. Maka berdasarkan hal tersebut jelaslah budaya punk yang hadir di Aceh merupakan hasil dari pengadopsian culturalisasi budaya asing. Perilaku ini diduga disebabkan oleh budaya meniru (budaya ikut-ikutan) dan pengaruh budaya asing yang secara langsung diterima tanpa ada filter dari dalam diri. 
Berdasarkan hal tersebut di atas, maka selanjutnya artikel ini akan mengkaji dan kemudian mendeskripsikan perilaku menyimpang komunitas punk yang ada di Aceh dari perspektif differensial association. Dalam hal ini akan dikaji komunitas punk sebagai salah satu bentuk perilaku menyimpang dan punk dari perspektif differential association. Studi ini termasuk penelitian deskriptif, yang merupakan penelitian yang didasarkan pada fakta yang ada atau fenomena yang memang secara empiris ada pada masyarakat sehingga apa yang dihasilkan adalah paparan apa adanya. Dalam melakukan studi ini, penulis melakukan observasi pada seputaran wilayah kota Banda Aceh, tempat dimana komunitas punk ini berkumpul serta melakukan wawancara terbuka terhadap beberapa anak usia remaja yang bergabung dalam komunitas punk tersebut. Kemudian dari hasil amatan dan wawancara tersebut, dikaji dengan menggunakan teori-teori yang revelan. Selanjutnya, dengan menganalisis fakta yang terjadi, maka akan terjawab persoalan komunitas punk di Aceh dari perspektif differential association.

\section{Landasan Teori}

a. Perilaku penyimpangan

Perilaku menyimpang dianggap menjadi sumber masalah sosial karena dapat membahayakan tegaknya sistem sosial. Soekanto menyatakan bahwa perilaku menyimpang dapat diidentifikasikan dalam dua tipe penyimpangan yaitu penyimpangan murni dan penyimpangan tersembunyi atau penyimpangan terselubung (1988; h.19).

Adapun teori-teori penyimpangan yang menjadi acuan atau landasan dari pengkajian artikel ini adalah :

- Teori Penyimpangan secara umum

Teori-teori penyimpangan secara umum yang akan dibahas berikut ini didasarkan pada dua teori, yaitu teori tentang patologi sosial dan teori tentang disorganisasi sosial.

Konsep tentang patologi sosial berkembang pada tahun 1980-an dan dianut kira-kira akhir tahun1930-an. Kondisi menyimpang adalah kondisi yang mengganggu masyarakat. Kondisi seperti kejahatan, bunuh diri, mabuk, kemiskinan, sakit jiwa, pelacuran dan sebagainya, adalah menyimpang karena dianggap buruk atau patalogi (penyakit).

Berdasarkan pandangan ini, penyimpangan adalah kesakitan atau menyimpang dari norma sehat yang telah ditetapkan oleh banyak orang. Asumsi pendekatan ini didasari oleh 
keyakinan bahwa ada kondisi sakit tertentu dalam masyarakat dan individu tertentu yang sakit. Lama kelamaan berkembang pandangan bahwa kondisi seperti tidak berpendidikan dan tidak bermoral karena kemiskinan adalah patologi sosial yang kemudian dikenal sebagai penyimpangan.

Selanjutnya adalah penyimpangan dalam konteks disorganisasi sosial, yaitu hasil ketidakseimbangan dalam masyarakat, dengan adanya banyak perubahan sosial dan konflik yang memengaruhi perilaku individu. Teori disorganisasi sosial memandang bahwa masyarakat akan terbentuk ketika orang telah mempunyai kesepakatan umum tentang nilai dan norma fundamental seperti yang dicerminkan ke dalam banyak perilaku yang teratur.

- Teori sosiologi perilaku menyimpang

Teori-teori sosiologi tenang penyimpangan dapat dibagi menjadi dua jenis, yaitu; structural dan prosesual. Teori structural memandang penyimpangan berdasar kondisi-kondisi structural di masyarakat. Sedangkan teori prosesual menggambarkan prosesproses yang dialami individu sehingga melakukan penyimpangan.

- Teori differential Association

Dalam sosiologi, dikenal beberapa teori interaksi untuk menjelaskan penyimpangan. Edwin $\mathrm{H}$. Sutherland, melalui teori yang diciptakannya differential association berpendapat bahwa penyimpangan bersumber pada pergaulan yang berbeda. Penyimpangan di pelajari melalui proses alih budaya (cultural transmission). Melalui proses belajar ini, seseorang mempelajari suatu subkebudayaan menyimpang. Contoh yang diajukan Sutherland adalah proses menghisap ganja, tetapi proses yang sama berlaku pula dalam mempelajari beraneka jenis perilaku menyimpang lainnya (Sunarto, 1993: 76).

Bila dijabarkan maka dapat diperlihatkan bahwa Sutherland melalui teorinya berpendapat (Siahaan, 2009: 107):

-Kejahatan merupakan perilaku yang dipelajari oleh individu dengan cara yang sama dan memiliki pola dengan unsurunsur budaya yang lainnya. 
-Kejahatan yang dilakukan dipelajari ketika terjadi interaksi dengan individu-individu lain dalam proses komunikasi.

- Ketika melakukan interaksi, maka terdapat hubungan antar individu dengan kelompok erat atau intim. Maksudnya, ketika kita bergaul dengan para pengguna obat-obatan terlarang, kita akan terpengaruh untuk menggunakan obatobatan terlarang juga.

-Yang dipelajari individu ketika mempelajari perilaku kejahatan meliputi teknik melakukan kejahatan, dorongan dan motivasi yang khas, serta rasionalitas dan sikap.

- Motivasi dan dorongan yang khas dipelajari ketika individuindividu tadi dihadapkan pada aturan hukum yang harus dipatuhi maupun yang lebih menjurus ke pelanggaran hukum.

- Hal ini juga tergantung pada frekuensi, durasi, prioritas, dan intensitas dengan aturan perilaku yang bersangkutan.

- Mempelajari perilaku tersebut dilakukan melalui mekanisme tertentu.

- Teori Sub Budaya

Menurut Albert Cohen, munculnya penyimpangan diawali oleh adanya status frustasi yang pada akhirnya mengarahkan pada subbudaya menyimpang. Masuknya subbudaya ini karena individu tidak dapat memenuhi standard yang telah ditetapkan oleh kebudayaan dominan. Dengan adanya subbudaya menyimpang ini mereka dapat merumuskan nilai dan norma yang dapat diinternalisasikan ke dalam kelompok mereka. Cohen membedakan tiga tipe anak (Siahaan, 2009: 121):

- Anak Sekolahan

Tipe ini merupakan cerminan dari anak-anak yang meraih sukses dengan cara yang benar. Misalnya dengan sekolah, bekerja dan lainnya.

- Anak Jalanan

Tipe ini lebih cenderung ke penarikan diri dari masyarakat dengan membentuk subbudaya baru. Mereka memiliki nilainilai sendiri dalam kelompoknya.

- Anak Dilikuen 
Tipe ini lebih memperlihatkan kefrustasian untuk memperoleh status social tinggi dengan cara-cara konvensional. Anak tipe ini kemudian mengembangkan subbudaya delikuen.

\section{Pembahasan}

\section{a. Punk sebagai salah satu bentuk perilaku menyimpang}

Punk adalah suatu komunitas anak muda yang pertama sekali muncul di London, Inggris dan kemudian merambah ke Negaranegara Eropa. Punk muncul sebagai bentuk reaksi masyarakat terutama kaum muda yang kondisi perekonomiannya lemah dan pengangguran di pinggiran kota-kota Inggris. Punk awalnya dibentuk sebagai golongan anti-pemerintah. Ini terlihat dari genre music dan lirik lagu yang mereka bawakan, mengandung unsur kritik terhadap pemerintah dan sarat membela rakyat kecil kelompok remaja dan kaum muda ini merasa bahwa sistem monarkilah yang menindas mereka. Dari sini muncul sikap resistensi terhadap sistem monarki. Kemarahan-kemarahan ini diwujudkan dalam bentuk musik yang berisi lirik-lirik perlawanan dan protes sosial politik serta cara berpakaian yang tidak lazim.

Berdasarkan hal tersebut, diketahui bahwa pada dasarnya tujuan dari punk itu sendiri bukanlah untuk membuat keonaran, tetapi sebagai bentuk protes terhadap kebijakan-kebijakan pemerintah pada saat itu, namun pada perkembangannya mereka justru berperilaku yang tidak lazim pada kebiasaan masyarakat dan nilainilai masyarakat pada umumnya. Komunitas punk ini hidup berpedoman pada tanpa aturan, artinya bahwa aturannya disepakati oleh kelompok mereka sendiri. Sehingga dalam tinjauan teori-teori sosial mereka dianggap sebagai salah komunitas yang telah melanggar norma-norma dan nilai-nilai kehidupan atau dapat dikatakan sebagai kondisi perilaku menyimpang.

Bentuk-bentuk penampilan mereka yang dianggap tidak lazim seperti penampilan rambut jingkrak (Mohawk), tindikan dibagian tubuh tertentu, pakaian ketat serba hitam, dan sebagian bertato, membuat masyarakat menilai punk sebagai komunitas yang negatif yang mengarah pada penyimpangan sosial. 
James vander Zanden dalam buku "Pengantar Sosiologi" mendefinisikan penyimpangan merupakan perilaku yang oleh sejumlah besar orang dianggap sebagai hal yang tercela dan diluar batas toleransi (Sunarto, 1993: 74). Penyimpangan terjadi akibat perilaku yang tidak lazim atau tidak dapat diterima oleh masyarakat. Namun, penyimpangan bukanlah merupakan suatu kejahatan. Jokie Siahaan dalam bukunya memaparkan bahwa penyimpangan belum tentu merupakan kejahatan, namun kejahatan pastinya adalah penyimpangan (Siahaan, 2009: 7). Begitu pula punk, komunitas ini terkadang bukanlah suatu komplotan penjahat, namun perilaku yang dicerminkan, diluar batas kelaziman.

Punk digolongkan dalam salah satu bentuk perilaku menyimpang karena perilaku yang ditampilkan oleh komunitas tersebut tidak sesuai dengan norma-norma yang berlaku dalam masyarakat Aceh. Hal ini sejalan dengan apa yang dikemukakan Soetomo dalam bukunya "Masalah Sosial dan Upaya Pemecahannya" bahwa tolok ukur seseorang dikatakan menyimpang apabila melanggar aturan yang ada dalam kelompoknya, artinya bahwa, dianggap atau tidak sebagai sebuah perilaku menyimpang apabila sebuah kelompok atau masyarakat telah membuat sebuah kesepakatan. Karena terkadang masyarakat berbeda-beda dalam menerjemahkan perilaku menyimpang, apalagi kondisi Indonesia yang sangat heterogen penduduknya.

Munculnya punk sebagai perilaku menyimpang dapat disebabkan oleh faktor frustasi terhadap norma yang berlaku dalam masyarakat. Menurut Albert Cohen, munculnya penyimpangan diawali oleh adanya status frustasi yang pada akhirnya mengarahkan pada subbudaya menyimpang. Masuknya subbudaya ini karena individu tidak dapat memenuhi standard yang telah ditetapkan oleh kebudayaan dominan. Dengan adanya subbudaya menyimpang ini mereka dapat merumuskan nilai dan norma yang dapat diinternalisasikan ke dalam kelompok mereka (Siahaan, 2009: 121). Punk dapat dikatakan sebagai wujud dari subbudaya yang frustasi akan hidup dan pada akhirnya membuat subbudaya sendiri dengan norma yang diinginkannya sendiri. Namun dewasa ini, pembentukan subbudaya ini bukan karena frustasi akan masalah tertentu, melainkan dikarenakan trend atau ikut-ikutan.

Setelah mencermati beberapa teori diatas, tentunya dapat dipahami subbudaya yang bernilai negatif ini merupakan suatu 
bentuk penyimpangan. Ini terlihat dari sikap punker (anak punk) yang meresahkan masyarakat. Bagaimana tidak, setelah penampilan, sikap mereka pun membuat resah. Punker yang marak dengan aliran music punk rocknya, aktivitas kumpul-kumpul (kongkow) dipinggir jalan atau taman kota bahkan tempat tersebut juga dipakainya menjadi tempat tidur, tidak mandi, meninggalkan aktivitas sekolah dan ibadah, bahkan ada diantara mereka yang memakai obat terlarang. Bentuk kegiatan yang meresahkan masyarakat seperti ini jelas menggolongkan punk merupakan bentuk dari penyimpangan sosial.

Perilaku punk tentu saja melanggar ketertiban umum. Dan yang menjadi kekhawatiran adalah merosotnya akhlak dan pendidikan mereka karena ketidakpedulian mereka terhadap pendidikan (padahal mereka masih diusia sekolah) dan tak jarang mengkonsumsi narkoba hingga bermabuk-mabukan.

Dikarenakan memang aktivitas yang mengarah pada penyimpangan, maka sudah selayaknya jika dilakukan penertiban. Upaya penertiban punk telah dilakukan sejak dulu oleh pemerintah Indonesia, sehingga punk tidak menjamur seperti yang terlihat sekarang ini. Di Aceh, penertiban besar-besaran terhadap punk, telah dilakukan pemerintah kota Banda Aceh (ibukota provinsi Aceh) pada tanggal 10 Desember 2011. Penertiban ini dilakukan langsung oleh Walikota dan Wakil Walikota Banda Aceh. Ini merupakan hal yang sangat berani dan harusnya ini diikuti oleh pemerintah di provinsi lain karena keresahan akan punk di daerah lain lebih nyata terlihat bila dibandingkan Aceh.Walaupun dalam penertiban punk di Aceh, pada nyatanya tetap menjadi kontroversi yang tak habisnya dibahas di media massa.

\section{b. Faktor-faktor maraknya anak punk di Aceh}

Dalam pandangan beberapa kaum muda, berpenampilan sebagai punker ini dianggap suatu penampilan yang keren dan berani berbeda. Sehingga, tidak sedikit remaja yang bergabung dalam komunitas ini dikarenakan hanya ikut-ikutan agar terlihat keren. Padahal mereka tidak mengerti esensi punk dalam arti sebenarnya. Hal ini terbukti berdasarkan hasil wawancara terbuka dengan salah seorang anak punk, bahwa setelah beberapa tahun bergabung dalam dunia punk, anak tersebut tidak mengerti ideologi yang mendasari punk tersebut. 
Faktor lain yang menyebabkan anak-anak usia remaja bergabung dalam komunitas ini adalah dikarenakan putus sekolah. Putus sekolah diusia remaja menyebabkan remaja tersebut sulit diterima dalam dunia kerja. Sehingga, pengangguran dalam usia remaja pun terjadi. Hal tersebut menyebabkan adanya upaya penarikan diri dalam masyarakat, sehingga cenderung menjadi anak jalanan yang kemudian melakukan perilaku penyimpang.

Selanjutnya, faktor lingkungan juga menyebabkan remajaremaja usia sekolah bergabung dalam komunitas ini. Salah seorang yang menjadi informan, mengakui bahwa pada awalnya dia bergabung dalam komunitas punk, disebabkan oleh pengaruh teman. Adanya teman yang sudah terlebih dahulu bergabung dan mempengaruhi teman yang lain untuk ikut bergabung merupakan hal yang paling banyak ditemukan. Ajakan tersebut menjadikan anak tersebut keenakan sehingga muncul rasa ketergantungan yang berlebihan.

Faktor keluarga juga menjadi alasan penting sehingga menyebabkan beberapa anak terlanjur melibatkan diri dalam komunitas Punk. Kurangnya perhatian keluarga salah satu faktor penyebab beberapa remaja mencari keluarga baru yang memberi perhatian lebih. Menurut pengakuan salah satu anak punk yang diwawancarai, mereka lebih mendapatkan kenyamanan ketika berada didalam lingkungan komunitas punk dibandingkan berada dalam lingkungan keluarga mereka sendiri. Faktor kurang betahnya remaja dirumah bisa disebabkan oleh beberapa alasan, yaitu orangtua yang sibuk bekerja sehingga tak punya waktu lebih untuk anaknya, orang tua yang hidup tidak harmonis lagi dan juga orangtua yang bercerai. Sehingga, menjalani kehidupan sebagai anak punk menjadi bentuk aksi protes mereka terhadap kehidupan mereka yang sebenarnya.

\section{c. Punk dalam perspektif differential association}

Era globalisasi tentunya segala sesuatu terjadi dengan perubahan yang begitu cepat, informasi dapat diakses dalam hitungan detik, dunia terasa berada di dalam genggaman. Di Era globalisasi juga akan terjadi proses transfer budaya yang begitu cepat melalui proses media informasi. Di era globalisasi, dunia seperti dipersatukan baik dibidang sosial, budaya, ekonomi dan pendidikan. Di satu sisi, era globalisasi dapat memberikan dampak positif,seperti: dapat 
menghemat waktu, hasil kerja menjadi cepat, produktivitas meningkat. Namun, disisi lain ternyata globalisasi juga memberikan dampak yang negatif, salah satunya adalah budaya punk yang notabenenya bukan budaya Indonesia, justru sampai di Indonesia dan kemudian dianut oleh sebagian kecil anak-anak muda di Indonesia. Lalu kemudian mengapa demikian cepat budaya ini diadopsi oleh sebagian masyarakat Indonesia khususnya Aceh? Hal ini dikarenakan terjadinya proses interaksi antar berbagai kebudayaan. Berbicara mengenai interaksi, tentunya tidak hanya interaksi fisik semata, namun non fisik juga, salah satunya adalah bagaimana anak-anak muda Indonesia membuka situs-situs yang menyampaikan informasi tentang punk, yang pada akhirnya budaya tersebut diadopsi oleh sebagian anak-anak muda Indonesia.

Disisi lain juga dapat terjadi interaksi langsung atau kontak langsung dengan kebudayaan yang berbeda, karena sudah begitu banyak punk di Indonesia dan telah menjamur, maka akan terjadi proses transfer kebudayaan pada individu-individu yang lain melalui proses interaksi sosial dan komunikasi. Seperti yang telah disampaikan oleh Sutherland dalam (Siahaan, 2009: 107), bahwa perilaku menyimpang yang dilakukan dan dipelajari ketika terjadi interaksi dengan individu-individu lain dalam proses komunikasi.

Perilaku menyimpang juga dapat terjadi melalui proses alih budaya (cultural transmission). Melalui proses belajar ini, seseorang mempelajari suatu subkebudayaan menyimpang. Contohnya Punk di Aceh tidak lahir di Aceh, namun perilaku ini di transfer oleh Punk yang ada diwilayah Indonesia lainnya, kemudian punk juga tidak lahir di Indonesia, namun punk lahir di Inggris. Pertanyaan kemudian adalah mengapa punk dapat berkembang di Aceh, jawabannya adalah terjadinya proses alih budaya yang kemudian berdampak bermunculannya punk di Aceh artinya terjadinya proses belajar diantara anak-anak muda Aceh dengan Punk atau sub kebudayaan yang baru.

\section{d. Upaya penanganan}

Kehadiran komunitas punk di Aceh tidak serta merta dibiarkan begitu saja. Pemerintah Aceh sendiri sudah melakukan upaya-upaya pembinaan remaja-remaja yang tergabung dalam komunitas punk tersebut pada akhir tahun 2011. Namun, penanganan yang tidak 
tuntas dan berkelanjutan menyebabkan komunitas punk ini masih terus ada sampai sekarang.

Hakikatnya, aspek struktural, pengangguran, kemiskinan, kenakalan remaja tidak dapat sepenuhnya disalahkan individu, seperti yang diutarakan oleh teori patologi sosial yang lama, individu merupakan sumber munculnya masalah sosial. Namun lebih dari itu, ternyata masalah sosial itu muncul akibat dari sistem sosial yang bermasalah dan juga akibat dari disfungsi structural. Artinya, kebijakan-kebijakan pemerintah kurang peduli terhadap masalahmasalah sosial. Hal ini bisa saja dikarenakan masalah-masalah sosial yang ada terkadang tidak begitu jelas terlihat dengan kasat mata.

Beberapa tawaran dari upaya penanganan masalah punk yang ada di Aceh adalah sebagai berikut:

1. Pembinaan yang berkelanjutan dan berintegrasi terhadap anak punk dengan memberikan pendidikan atau keterampilan khusus bagi yang putus sekolah.

2. Kebijakan- kebijakan yang dibuat oleh pemerintah lebih difokuskan pada masalah-masalah sosial.

3. Sistem pendidikan harus ditingkatkan kualitasnya.

4. Control sosial menjadi sangat penting termasuk control keluarga, karena masalah itu lahir dari masyarakat, jadi masyarakat sendiri yang menilai dan mengontrol agar tidak terjadinya perilaku menyimpang.

\section{Kesimpulan}

Adapun yang dapat disimpulkan oleh penulis adalah; penyimpangan dewasa ini kerap menghinggapi kehidupan remaja usia sekolah yang labil dan sarat akan mengikuti perkembangan zaman tanpa ada filter dalam diri. Oleh karena itu pengawasan terhadap remaja perlu ditingkatkan baik dengan control keluarga ataupun control masyarakat.

Dua hal yang dapat menyebabkan penyimpangan sosial dapat terjadi, pertama akibat interaksi sosial baik langsung maupun tidak langsung, kedua, dalam kehidupan masyarakat tentunya tidak terlepas dari proses belajar yang terus menerus, penyimpangan sosial dapat terjadi melalui proses belajar dalam kelompok masyarakat tertentu. Kedua hal ini kemudian melatar belakangi terjadinya penyimpangan sosial yang terjadi di Aceh dalam bentuk komunitas Punk. 
Community: Volume 1, nomor 1, Oktober 2015

\section{Referensi}

Budiardjo, Miriam. 2009. Dasar-Dasar Ilmu Politik. Jakarta: PT. Gramedia Pustaka Utama

Patilima, Hamid. 2007. Metode Penelitian Kualitatif. Bandung: Penerbit Alfabeta

Siahaan, Jokie M.S. 2009. Perilaku Menyimpang: Pendekatan Sosiologi. Jakarta: PT. Indeks

Jones, PIP. 2009. Pengantar Teori-Teori Sosial. Jakarta: Yayasan Obor Indonesia.

Sunarto, Kamanto. 1993. Pengantar Sosiologi. Jakarta: Fakultas Ekonomi Universitas Indonesia.

Soekanto, Soerjono. 1975. Sosiologi Suatu Pengantar. Jakarta: Yayasan Penerbitan Universitas Indonesia.

Soetomo. 2008. Masalah Sosial dan Upaya Pemecahannya. Yogyakarta: Pustaka Pelajar. 